\title{
BANK DAN LEMBAGA KEUANGAN SYARIAH DALAM PERSPEKTIF AL-QUR'AN
}

\author{
Dewi Maharani' ${ }^{1}$, Taufiq Hidayat ${ }^{2}$ \\ 1,2 Universitas Muhammadiyah Banjarmasin \\ $\triangle$ dewimaharani922@gmail.com
}

\begin{abstract}
: The Qur'an is the main source of Islamic teachings and is a reference for Muslims in understanding the Shari'a. In the Al-Qur'an there is no text that mentions the word bank, but in practice banking has been done since the time of the Prophet Muhammad. The Qur'an and Sunnah only provide basic principles and philosophies, and emphasize prohibitions that must be avoided. Thus, all that has to be done is to identify the things that are prohibited by Islam.
\end{abstract}

Keywords $\quad$ : Bank, Islamic Financial Institutions, Al-Qur'an,

\section{LATAR BELAKANG}

Dalam islam uang sebagai alat tukar yang bertolak dari adanya ketidaksesuaian dalam alat tukar sebelum adanya uang, yaitu barter (menukar barang dengan barang). Barter dalam transaksi yang terjadi seringkali mempunyai nilai yang berbeda dengan barang yang akan ditukar, baik dalam jenisnya, kualitasnya maupun kuantitasnya. Maka, barter digolongkan sebagai riba fadl yang dilarang oleh agama. Islam membenarkan uang sebagai alat tukar karena uang sendiri tidak menghasilkan apa-apa kecuali jika ditukarkan.

Dalam ekonomi syariah, uang memiliki peranan yang sangat penting baik dari segi sosial maupun religi, misalnya dalam kegiatan religi uang dapat digunakan sebagai pembayaran zakat, sedekah dan infak. Sedangkan dalam kegiatan sosial, uang memberikan fungsi sebagai pencegah ekspolitasi terbuka yang terkandung dalam suatu keadaan tawar menawar tanpa akhir (Manan,1997:163).

Berdasarkan paparan diatas, dalam islam uang tidak menghasilkan apa-apa (bunga atau laba) dan tidak dipandang sebagai komoditi. Bunga (riba) dilarang, maka dengan begitu bank dan lembaga keuangan syariah menjalankan produknya disesuaikan dengan syari'at Islam yaitu tidak mengandung unsur-unsur terkait riba. Produk yang dimiliki oleh bank syariah antara lain mudharabah dan musyarakah menggunakan sistem bagi hasil, maka laba yang didapatkan dihitung dengan presentase yang telah disepakati. Sedangkan produk Murabahah, Istishna' dan Salam merupakan akad jual beli yang mengandung rasio laba yang telah disepakati kedua belah pihak. 


\section{TEORI DAN METODE}

\subsection{Metode Penelitian}

Kajian ini menggunakan metode penelitian analisis deskriptif. Jenis data yang digunakan adalah data sekunder, data dalam bentuk artikel, buku dan laporan penelitian serta sumber-sumber lain atau informasi yang relevan dengan kajian ini. Kemudian teknik pengumpulan data yang digunakan adalah studi literatur atau library research. Studi kepustakaan adalah kegiatan yang berkaitan dengan koleksi data perpustakaan, membaca, merekam, dan mengolah bahan penelitian.

Analisis data yang digunakan adalah deduktif yaitu menganalisis data penulis, dan bertolak dari kesimpulan atau pengetahuan yang bersifat umum, kemudian ditarik kesimpulan data fakta atau pendapat para ahli tentang suatu masalah tertentu, kemudian diuraikan pula aspek-aspek persamaan dan perbedaan tentang objek yang dikaji. Menurut Mestika Zed dalam bukunya yang berjudul Metode Penelitian Kepustakaan, ada empat langka penelitian kepustakaan yaitu; Pertama, menyiapkan alat perlengkapan. Kedua, menyusun bibliografi kerja. Ketiga, mengatur waktu. Keempat, membaca dan membuat catatan penelitian (Mestika Zed, 2014).

\section{HASIL DAN PEMBAHASAN}

\subsection{Perbankan pada masa Rasulullah}

Pada masa sekarang ini, kegiatan ekonomi tidak akan sempurna tanpa adanya lembaga keuangan, baik secara syariah maupun konvensional. Maka dari itu perbankan dan lembaga keuangan syariah menjadi hal yang wajib diadakan. Dalam ushul fiqh ada kaidah yang berbunyi " مالايتم الواجب الا به فهو واجب " yakni dimana sesuatu yang wajib yang tidak sempurna kecuali dengan sarana ini, maka sarana ini menjadi wajib.

Perbankan atau lembaga keuangan merupakan bagian dalam muamalah, Nabi Muhammad SAW tidak memberikan secara rinci atau detail terkait pada aturan ini. Namun, Nabi pernah menyatakan "أنتم أعلم باموردنياكم" (kalian lebih mengetahui urusan dunia kalian). Filosofi dan prinsip-prinsip dasar ada pada Al-Qur'an dan Sunnah dengan menegaskan larangan-larangan yang harus dijauhi. Dengan begitu, yang menjadi keharusan adalah mengidentifikasi hal-hal yang dilarang oleh Islam. Selain itu, semuanya diperbolehkan dan dapat dilakukan inovasi dan kreativitas sebanyak mungkin.

Sejarahnya ekonomi umat Islam, dibangun secara syariah dengan menggunakan akad yang sesuai dengan ajaran islam dan menjadi sebuah tradisi umat Islam sejak masa Rasulullah. Aktivitas ekonomi yang dibangun seperti meminjamkan uang, melakukan pengiriman uang, telah ada sejak zaman Rasulullah. Kegiatan tersebut merupakan fungsi-fungsi utama dari kegiatan perbankan pada masa ini, yaitu menerima tabungan nasabah, baik deposit maupun tabungan tidak berjangka, menyalurkan dana dan melakukan transfer dana telah menjadi bagian yang tak terpisahkan dari kehidupan umat Islam, bahkan sejak zaman Rasulullah.

Pada hakikatnya kegiatan lembaga keuangan sudah dijalankan oleh Rasulullah sendiri dan para sahabat ketika itu. Sebagai contoh saat Rasulullah SAW sebelum melakukan perjalanan (hijrah) ke Madinah dipercaya masyarakat Makkah menerima 
simpanan harta, kemudian Rasulullah SAW meminta Sayyidina Ali untuk mengembalikan titipan tersebut sebelum hijrah. Dan Sahabat Zubair bin al-Awwam melakukan praktek pinjam-meminjam, karena beliau tidak suka untuk menerima titipan. Sahabat lain, Abdullah bin Zubair juga melakukan pengiriman uang untuk adiknya Misab bin Zubair yang tinggal di Irak. Bahkan Khalifah Umar bin Khattab melakukan penggunaan cek untuk membayar tunjangan kepada yang berhak. Dengan cek tersebut mereka mengambil gandum di Baitul Mal untuk diimpor ke Mesir(Adiwarman Karim,2004:18-19). Dan sistem pemberian modal dengan berbasis bagi hasil seperti mudharabah dan musyarakah telah dikenal sejak awal antara kaum muhajirin dan kaum anshor.

Dari penjelasan diatas, jelas tergambar bahwasanyan fungsi dari lembaga keuangan atau perbankan pada masa itu dilakukan oleh perorangan. Pada zaman Abbasiyah kemajuan aktivitas lembaga keuangan ditandai dengan beredarnya saq (cek) secara luas sebagai alat pembayaran. Bahkan, peranan bankir telah meliputi tiga aspek, yakni menerima deposit, menyalurkan, dan mentransfer uang. Dalam sejarah perbankan Islam, yang tercatat sebagai orang pertama yang menerbitkan cek untuk kliring antara Baghdad dan Aleppo (Spanyol) adalah Sayf al-Dawlah al-Hamdani (Sudi Haron,1997:2).

\subsection{Bank dan Lembaga Keuangan Syari'ah}

Sebagai wujud komitmen keimanan dengan bersikap lebih mengutamakan bank dan lembaga keuangan syariah sesungguhnya merupakan bagian dari kesadaran untuk menerapkan Islam secara utuh dan total. Dalam QS. Al Baqarah ; 85 Allah menegaskan: "Apakah kalian beriman kepada sebagian Alkitab (Taurat) dan ingkar terhadap sebagian yang lain ? Tiadalah balasan bagi orang-orang yang berbuat demikian daripada kalian, melainkan kenistaan dalam kehidupan dunia, dan pada hari kiamat mereka dikembalikan kepada siksa yang sangat berat. Allah tidak lengah dari apa yang kalian perbuat."

Pada surat yang sama ayat 208:"Hai orang-orang yang beriman, masuklah kamu kedalam Islam secara Kaffah (keseluruhan), dan janganlah kamu turuti langkahlangkah setan. Sesungguhnya setan itu musuhmu yang nyata." Kedua ayat tersebut dengan tegas dengan menerapkan Islam secara parsial, kita akan mengalami keterpurukan duniawi dan kerugian ukhrawi.

Selama islam hanya ditunjukkan dengan ritual ibadah saja, sementara dimarginalkan dari aktivitas perbankan dan lembaga keuangan lainnya maka umat islam telah mengubur Islam dalam-dalam dengan tangannya sendiri. Sebagai akibatnya umat islam tidak memiliki konsep apapun tentang bisnis dan keuangan. Kalaupun ada terbatas kepada zakat, waris, waqaf, shadaqah, atau jual beli dan sewa menyewa yang sederhana saja.

Secara sistem bank dan lembaga keuangan Syari'ah sebenarnya lebih unggul disbanding dengan konvensional. Sebagai contoh pada masa saat Indonesia mengalami krisis moneter beberapa tahun lalu telah membuktikan bahwa bank Syari'ah mampu untuk bertahan bahkan memberikan profit pada saat industri perbankan nasional nyaris ambruk. Contoh bank nasional pada masa krisis moneter mengalami dampak Bank BNI, Bank BTN, Bank Mandiri (dahulu Bank EXIM, Bapindo, BBD dan BDN) dan Bank swasta seperti BCA, Danamon, BII, Lippo, masih selamat karena disuntik BLBI oleh pemerintah. Sementara ada puluhan Bank yang tidak dibantu harus tutup dengan meninggalkan segudang beban finansial yang harus ditanggung negara dan rakyat. 
Di dalam al-Qur'an istilah bank disebutkan secara eksplisit. Namun, jika yang dimaksudkan adalah sesuatu yang memiliki unsur struktur, manajemen, fungsi, hak dan kewajiban, maka semua itu disebutkan dengan jelas seperti contoh, zakat, bai' (jual beli), al-dayn (utang dagang), maal (harta), dan sebagainya.

Kata bank diambil dari kata banque dalam bahasa Perancis, dan dari banco dalam bahasa Italia, yang berarti peti/lemari atau bangku. Kata peti menyiratkan fungsi sebagai tempat menyimpan benda-benda berharga (Heri Sudarsono,2003:27). Kata "syari'ah" berasal dari bahasa Arab, secara harfiah berarti jalan yang ditempuh atau garis yang mesti dilalui. Secara terminologi, syari'ah adalah peraturan-peraturan dan hukum yang telah digariskan oleh Allah, atau telah digariskan pokok-pokoknya dan dibebankan kepada kaum muslimin supaya mematuhinya, supaya syari'ah ini diambil oleh orang Islam sebagai penghubung diantaranya dengan Allah dan diantaranya dengan manusia.

Bank sebagaimana diketahui adalah satu lembaga yang melakukan tiga fungsi utama yakni menerima simpanan uang, meminjamkan uang dan memberikan jasa pengiriman uang. Dalam Fiqih Islam (kaidah hukum-hukum Islam) tidak ada kata Bank, namun bukti sejarah menyatakan bahwa fungsi-fungsi perbankan sudah dipraktekkan oleh umat Islam sejak zaman Nabi Muhammad SAW. Praktek-praktek perbankan ini tentunya berkembang secara perlahan dan berangsur-angsur, bahkan mengalami kemajuan dan kemunduran dimasa tertentu sesuai dengan naik-turunya peradaban manusia (Adiwarman Karim,2004:7).

Bank syari'ah yang dimaksud dalam hal ini adalah bank Islam yang melaksanakan kegiatan usahanya berdasarkan prinsip Islam yaitu aturan perjanjian (akad) antara bank dan pihak lain (nasabah) berdasarkan hukum Islam. Sehingga perbedaan antara bank Islam (syari'ah) dan bank konvensional terletak pada prinsip dasar operasinya yang tidak menggunakan bunga, akan tetapi menggunakan prinsip bagi hasil, jual beli dan prinsip lain yang sesuai dengan syari'at Islam (Veithzal Rivai,2007:753).

\subsection{Kegiatan Bank dan Lembaga Keuangan Syariah dalam Al-Qur'an dan Hadits}

Didalam al-Qur'an dan Hadits tidak ditemukan nash yang menyebutkan perbankan, namun secara praktek sudah dilakukan sejak zaman Nabi Muhammad SAW. Berikut kegiatan bank yang berlandaskan pada ayat al-Qur'an dan Hadits. Dikategorikan menjadi tiga kategori, yaitu), produk penghimpunan dana (funding), produk penyaluran dana (financing) dan produk jasa (sevices).

\subsection{A Penghimpunan Dana (Funding)}

\subsection{A.1 Wadi'ah}

Wadi'ah merupakan simpanan (deposit) barang atau dana kepada pihak lain yang bukan pemiliknya, untuk tujuan keamanan. QS. Al-Baqarah: 283 yang artinya: "Jika sebagian kamu mempercayai sebagian yang lain, Maka hendaklah yang dipercayai itu menunaikan amanatnya (hutangnya) dan hendaklah ia bertakwa kepada Allah Tuhannya. " dan Hadits HR. Abu Daud dan At-Tirmidzi_yang artinya "Tunaikanlah amanat itu kepada orang yang memberi amanat kepadamu dan jangan kamu mengkhianati orang yang mengkhianatimu"

\subsection{A.2 Mudharabah}

Mudharabah memiliki 2 jenis yaitu tabungan dan deposito, sehingga dengan akad mudharabah ini ada dua jenis menghimpun dana yaitu tabungan mudharabah dan deposito mudharabah. 


\subsection{A.2.1 Tabungan Mudharabah}

Adalah tabungan sistem penyetoran dan penarikannya dilakukan sesuai dengan perjanjian yang telah disepakati sebelumnya. Pada simpanan ini tidak diberikan bunga sebagai pembentuk laba bagi bank Syari'ah tetapi diberikan bagi hasil. Tabungan Mudharabah ini mempunyai berbagai bentuk: Tabungan Idul Fitri, Tabungan idul Qurban, Tabungan Haji, Tabungan Pendidikan, Tabungan Kesehatan, dll.

\subsection{A.2.2 Deposito Mudharabah}

Adalah simapanan pemilik dana yang hanya dapat diambil dalam waktu tertentu. Produk ini mencakup: Deposito Mudharabah 1,3,6,9,12,24 bulan.

\subsection{B Penyaluran Dana (Financing)}

Penyaluran dana yang dilakukan Bank dan lembaga keuangan Syari'ah mempunyai berbagai metode, diantaranya jual beli, bagi hasil, pembiayaan, pinjaman dan investasi khusus.

\subsection{B.1 Prinsip Jual Beli}

\section{a) Murabahah}

Secara istilah (fikih), murabahah adalah jual beli barang yang menjadi miliknya yang jual belinya dengan dilebihkan. Jual beli yang dimaksud adalah jual beli barang dagangan dengan tambahan harga (keuntungan) yang diketahui pembeli ( Nazîh hammâd,1993:243). Sehingga definisi Murabahah menjadi akad jual beli suatu barang dimana penjual menyebutkan harga jual yang terdiri atas harga pokok barang dan tingkat keuntungan tertentu atas barang, dimana harga jual tersebut disetujui oleh pembeli (IBI,2001:76). Dalam QS. Al-Baqarah: 275 yang artinya: “...Allah telah menghalalkan jual beli dan mengharamkan riba...". dan QS. An-Nisa`: 29 yang artinya:"Hai orang-orang yang beriman, janganlah kamu saling memakan harta sesamamu dengan jalan yang batil, kecuali dengan jalan perniagaan yang berlaku dengan suka sama suka di antara kamu...".

\section{b) Salam}

Salam adalah akad jual beli barang pesanan (muslam fih) dengan pengiriman dikemudian hari oleh penjual (muslam ilaih) dan pelunasannya dilakukan oleh pembeli pada saat akad disepakati sesuai dengan syarat-syarat tertentu ( Dwi Suwiknyo,2010:45). Dalam mu'jam al-Wasith disebutkan: as-Salaf diartikan dengan bai' as-salam yang artinya jual beli salam. Pengertian salaf atau istalafa: iqtaradha yang artinya berhutang (Ibrahim Anis,1992:44). Sedangkan dalam istilah, salam adalah suatu akad atas barang yang disebutkan sifatnya dalam perjanjian dengan penyerahan tempo dengan harga yang diserahkan dimajelis akad (Ahmad Wardi,2010:242). Dalam QS. Al-Baqarah: 282 yang artinya: " Hai orang-orang yang beriman, apabila kamu bermu'amalah tidak secara tunai untuk waktu yang ditentukan, hendaklah kamu menuliskannya. dan hendaklah seorang penulis di antara kamu menuliskannya dengan benar...".

\section{c) Istishna'}

Istishna' adalah akad jual beli dalam bentuk pemesanan pembuatan barang tertentu dengan kriteria dan persyaratan tertentu yang disepakati antara pemesan (pembeli/mustashni') dan pembuat (penjual/shani'). Hadits HR. Tirmidzi Amr bin Auf berkata: "perdamaian dapat dilakukan diantara kaum muslimin kecuali perdamaian yang mengharamkan yang halal dan menghalalkan yang haram, dan kaum muslimin 
terikat dengan syarat-syarat mereka mereka kecuali syarat yang mengharamkan yang halal dan mengalalkan yang haram".

\subsection{B.2 Prinsip Bagi Hasil}

\section{a) Musyarakah}

Secara bahasa berarti al-ikhtilath (percampuran) atau persekutuan dua orang atau lebih. Secara istilah, syirkah adalah perjanjian dua orang atau lebih yang berserikat mengenai pokok harta dan keuangannya (Sayyid Sabiq,1985:354). Didalam QS. An-Nisa': 12 yang artinya: “...jika saudara-saudara seibu itu lebih dari seorang, Maka mereka bersekutu dalam yang sepertiga itu...”, QS. Shaad: 24 yang artinya: "... dan Sesungguhnya kebanyakan dari orang-orang yang berserikat itu sebahagian mereka berbuat zalim kepada sebahagian yang lain, kecuali orang-orang yang beriman dan mengerjakan amal yang saleh..."

\section{b) Mudharabah}

Mudharabah berasal dari kata adh-dharbu fi al-ardh, yang artinya memukul atau bepergian, ini berarti bepergian atau memukulkan kakinya untuk berdagang atau menjalankan usaha. Disebut juga qiradh yang berasal dari kata al- qardhu yang berarti potongan, karena pemilik memotong sebagian hartanya untuk diperdagangkan dan memperoleh sebagian keuntungan (Al-Fiqh al-Islam 'ala Madzahib al-Arba'ah). Mudharabah adalah akad kerjasama usaha antara pemilik dana (shahibul mal) dan pengelola dana (mudharib) untuk melakukan kegiatan usaha, laba dibagi atas dasar nisbah bagi hasil menurut kesepakatan kedua belah pihak, sedangkan bila terjadi kerugian ditanggung oleh si pemilik dana kecuali disebabkan oleh misconduct, negligence, atau violation oleh pengelola dana (Sri Nurhayati\&Wasilah,2008:112).

Menurut ijma' ulama, mudharabah hukumnya jaiz (boleh). Hal ini diambil dari kisah Nabi Muhammad SAW yang pernah melakukan praktek mudharabah dengan Siti Khadijah. Siti Khadijah bertindak sebagai pemilik dana dan Nabi Muhammad SAW sebagai pengelola dana. Lalu Nabi Muhammad SAW membawa barang dagangannya ke negeri Syam. Dari kisah ini jelas bahwa praktek mudharabah sejatinya sudah ada ketika Nabi Muhammad SAW belum diangkat sebagai Rasul. Bahkan sebelum Islam datang pun praktek mudharabah ini sudah di lakukan para sahabat karena praktek ekonomi ini sangat bermanfaat. Ini diperkuat dalam ajaran Islam sebagaimana termaktub dalam al-Qur'an dan Hadits.

\subsection{Produk Jasa (Services)}

\subsection{C.1 Ijarah}

Ijarah didefinisikan sebagai akad pemindahan hak guna (manfaat) atas suatu barang atau jasa, dalam waktu tertentu dengan pembayaran upah sewa (ujrah), tanpa diikuti dengan pemindahan kepemilikan atas barang itu sendiri. Ijarah dimaksudkan untuk mengambil manfaat atas barang atau jasa (mempekerjakan seseorang) dengan jalan penggantian (membayar sewa atau upah sejumlah tertentu). Didalam QS. AzZukhruf: 3 yang artinya: "Apakah mereka yang membagi-bagi rahmat Tuhanmu? Kami telah menentukan antara mereka penghidupan mereka dalam kehidupan dunia, dan Kami telah meninggikan sebahagian mereka atas sebagian yang lain beberapa derajat, agar sebagian mereka dapat mempergunakan sebagian yang lain. dan rahmat Tuhanmu lebih baik dari apa yang mereka kumpulkan". Dan QS. Al-Baqarah: 233 yang artinya: “...dan jika kamu ingin anakmu disusukan oleh orang lain, Maka tidak ada dosa 
bagimu apabila kamu memberikan pembayaran menurut yang patut. bertakwalah kamu kepada Allah dan ketahuilah bahwa Allah Maha melihat apa yang kamu kerjakan". 


\section{PENUTUP}

Perbankan dan lembaga keuangan syariah pada zaman Rasulullah, jelas bahwa kosa kata "Bank" tidak terdapat dalam kitab-kitab klasik (Fiqih), dalam al-Qur'an pun tidak ada yang menjelaskan langsung tentang bank yang berkembang sekarang ini. Namun, dalam kegiatannya sudah ada dan berkembang berdasarkan syari'at Islam yang berlandaskan pada al-Qur'an dan Hadits. Bank dan lembaga keuangan syari'ah yang dimaksudkan dalam hal ini adalah bank Islam yang melaksanakan kegiatan usahanya berdasarkan prinsip Islam yaitu aturan perjanjian (akad) antara bank dan pihak lain (nasabah) berdasarkan hukum Islam. Bank Syari'ah dalam menjalankan usahanya minimal mempunyai lima prinsip operasional yang terdiri dari sistem pinjaman, bagi hasil, margin keuntungan, sewa dan jasa. 


\section{DAFTAR PUSTAKA}

Anis, Ibrahim, al-Mu'jam al-Wasith, juz 1, Dar Ihya at-Turats al-Arabiy, Kairo, 1992

Arifin Zainul. (2012). Dasar-dasar Manajemen Bank Syariah. In Pustaka Alvabet.

Hernandez, J. (2014). Perbankan Syariah. None.

Hammad, N. (1993). Mu'jam al-Mustalahat al-Iqtisadiyah fi Lughah al-Fuqaha'. Haron, S. (1997). Islamic banking: Rules \& regulations. Pelanduk publications.

Karim, A. (2004). Bank Islam Analisis Fiqih dan Keuangan, PT. Raja Grafindo Persada, Jakarta.

Khusairi, H. (2015). Hukum Perbankan Syariah. Al-Qisthu: Jurnal Kajian Ilmu-Ilmu Hukum. https://doi.org/10.32694/010120

Manan, M. A. (1997). Teori dan Praktek Ekonomi Islam terjemah dari "Islamic Economics, Theory and Practice", PT. Dana Bhakti Prima Yasa, Yogyakarta.

Mestika Zed. (2014). Metode Penelitian Kepustakaan (3rd ed.). Yayasan Pustaka Obor Indonesia.

Shandy Utama, A. (2020). PERKEMBANGAN PERBANKAN SYARIAH DI INDONESIA. UNES Law Review. https://doi.org/10.31933/unesrev.v2i3.121

Siringoringo, R. (2012). Perbankan Di Indonesia. Buletin Ekonomi Moneter Dan Perbankan.

Sudarsono, H. (2003). Bank \& lembaga keuangan syariah: deskripsi dan ilustrasi. Ekonisia.

Suparyanto, D. (2018). PROSPEK PERBANKAN SYARIAH DI INDONESIA. Al-Insyiroh: Jurnal Studi Keislaman. https://doi.org/10.35309/alinsyiroh.v2i2.3328

Syukron, A. (2013). Dinamika Perkembangan Perbankan Syariah Di Indonesia. Jurnal Ekonomi Dan Hukum Islam.

WijayaDenda. (2001). Manajemen Perbankan. Edisi Revisi Sembilan. https://doi.org/2009 